DOI 10.14746/ssp.2021.2.3

Serhiy DANYLENKo

Taras Shevchenko National University of Kyiv

ORCID ID: 0000-0003-3873-2525

Olena SHCHERBATIUK

Taras Shevchenko National University of Kyiv

ORCID ID: 0000-0003-3195-6323

\title{
Use of Russia's Information and Communication Technologies in Political Instrumentalization of Ukraine's History
}

\begin{abstract}
The political instrumentalization of the history of Ukraine carried out by the Russian Federation in the framework of the information war against Ukraine is covered in this article. This instrumentalization is exercised through media communication employing historical and political myths and narratives to vindicate Russia's aggressive actions. The latest information and communication technologies used by the Kremlin in the information war against Ukraine have been identified in this paper. Such destructive efforts often derail Ukrainian-Polish relations, which are particularly sensitive to historical and political issues. The reasons for the drawbacks of the Ukrainian authorities in counteracting the information aggression on the part of the Russian Federation are distinguished, and the measures that would contribute to an effective response to such aggression are outlined.
\end{abstract}

Key words: disinformation, Russia's information war against Ukraine, political instrumentalization of history, media

\section{Identifying the issue and its relevance}

ince the annexation of the Autonomous Republic of Crimea by the
Russian Federation and the active phase of Russia's hybrid war in
eastern Ukraine, Russia's political instrumentalization of Ukraine's
history has become significant. It is aimed at the disintegration of the
Ukrainian society, eroding and destroying the national consciousness,
historical memory, and the statehood of Ukraine as a whole. At the same
time, in Russia's information war against Ukraine, such political instru-
mentalization is also aimed at the third party, which is the international 
community, to convince the world of the legitimacy of the Russian Federation's actions against Ukraine. Russia imposes its values and beliefs on both Ukrainian and international society. It considers the European settlement after 1989 unacceptable and temporary and regards international claims to Russia's violation of human rights and the rule of law as deliberate delusion and naivety. This settlement includes such developments as the self-dissolution of the Polish United Workers' Party in 1990 and the cessation of the Polish People's Republic, the transformation of the Hungarian People's Republic into the Republic of Hungary, the collapse of the Berlin Wall, and the unification of Germany, the dissolution of Czechoslovakia and the formation of separate Czech and Slovak Republics, the transformation of the People's Republic of Bulgaria into the Republic of Bulgaria, the demise of the Ceausescu regime in Romania; the dissolution of Yugoslavia. Therefore, it is important to debunk Russia's actions by studying, covering, and communicating information to the general public.

\section{Analysis of the latest research and publications}

The use of information and communication technologies by the Russian Federation against Ukraine in the political instrumentalization of history as a component of information policy has been discussed by domestic and foreign scholars in the context of such problems as the concentration of pro-Russian media resources as a strategy of destructive information influence on Ukraine, the consequences of Russia's information aggression against Ukraine and the ways to overcome it - S. I. Danylenko; information warfare as a communicative technology of influencing mass consciousness and the civic opinion - A. G. Stadnyk; historical memory as a factor of political influence in the independent Ukraine - V. L. Bab$\mathrm{ka}$; information component of the hybrid war of the Russian Federation against Ukraine - I. D. Bondarenko; revision of history - J. Hrytsak, K. Halushko, J. Prymachenko; the purpose of Russian propaganda and how to counteract it - E. Lucas and P. Pomerantsev; the conspiracy theories and pro-Russian propaganda in the Eastern Partnership countries - A. Damian, V. Subernitchi; historical revisionism in Russia - W. Baluk; COVID-19 related Russian propaganda - J. Olchowski; the role of digital media in the Russian-Ukrainian war - A. Galus, Y. Nesteriak; Russia's hacking, misinformation and propaganda operations to foster polarization 
in Western democracies and Ukraine as well - M. Aaltola; Russia's memory politics on history of Eastern European countries - A. Miller; Russia's information campaign preceding, accompanying, and following Russian military operations in Crimea - M. Kofman; political manipulations of Russian elites of the collective memory of World War II and related antiUkrainian media campaign on main Russian TV channels - J. Sweet.

The purpose of this work is to study the application of information and communication technologies by the Russian Federation in the political instrumentalization of the history of Ukraine for the further development of communicative tools to counteract the destructive informational influence of third parties on common historical phenomena, as well as to outline in the author's assessment the essential characteristics of Russian propaganda that determine its effectiveness in this day and age. To achieve this goal, the political instrumentalization of the history of Ukraine carried out by the Russian Federation in the information war against Ukraine was highlighted; the latest information and communication technologies used by the Kremlin in the information war against Ukraine were identified; the use of historical and political myths and narratives by the Russian Federation in media outlets with the purpose of justification of their actions in the East of Ukraine and the Crimea was illustrated; the reasons for the drawbacks in counteracting Russia's information aggression by Ukrainian authorities and the measures that would contribute to an effective response were outlined.

\section{Presentation of the main research material}

Political instrumentalization of history is a mechanism of using historical politics by the state, political and cultural elites, various concerned groups related to the categories of society for which issues of the past are extremely relevant.

The political instrumentalization of history, which is at the heart of historical politics, remains important to these parties due to various reasons. For the state, it is a crucial element in creating a loyal civil society independent of whoever is ruling the country. For political and cultural elites, it is a means of social self-fulfillment and influence. For all concerned groups, which are constituent parts of elites mentioned, the political instrumentalization is a means of manipulation in the interests of current policies (Yablonsky, Valevsky, Zdioruk, 2019, p. 157). 
Political instrumentalization performs three main functions: 1) symbolism, which is to give meaning to a particular event or fact; 2) interpretation, which is implemented through the interpretation of a certain event or fact in the light necessary for the concerned party; 3 ) identification, the role of which is to influence the formation of national identity (Yablonsky, Valevsky, Zdioruk, 2019, p. 26). As a result, a consistent version of knowledge and ideas about the past in a specific interpretation necessary for stakeholders is formed.

Historical revisionism, presented in Russia as a struggle for historical truth, involves imposing own narrative on Russian history through information operations and propaganda. Russian propaganda activities are aimed at presenting the Russian Federation as a "peaceful state" and cultivating the myth of Russia as "the emancipator of Europe from Nazism" (Baluk, 2020, p. 15). On the part of the Russian Federation, these activities were observed in Crimea before and during the pseudo-referendum and its annexation when pro-Russian activists distributed propaganda leaflets and displayed historical propaganda videos in the public transport on TV channels and the streets. At the same time, only the Russian media had the right to broadcast and disseminate information, and the Ukrainian media were persecuted, which ultimately led to the situation that after the annexation of Crimea, no Ukrainian media outlets operated on the peninsula. A striking example is the story of television and radio broadcasting company "Breeze," the first and only military TV and radio company in Ukraine, which was established by order of the Minister of Defense of Ukraine on December 12, 1992 in Sevastopol to promote the ideas of the Ukrainian state among the Ukrainian Navy and the Crimeans in general. In April 2014, the company was forced to move to Odessa and reshape into a TV studio. However, its full-fledged activity has not been resumed today (SNIP, 2017).

Russia's goal in international relations is to position itself as the superpower and strengthen itself by transforming the current, largely institutionalized and liberal, international order so that the leading role belonged to the restricted group of superpowers, including Russia. Therefore, this would be a return to a kind of "concert of superpowers." To achieve this goal, Russia is taking measures in various methods, tools, directions, and recipients. As for the countries of the former Soviet Union, Russia's measures are aimed at keeping the states that currently exist in the postSoviet area under Russia's influence, limiting spreading Western ideals and values in these states and, finally, increasing their economic, cultural, military dependence on Russia (Olkhovskii, 2019, p. 216). 
In the context of political instrumentalization of the history of Ukraine conducted within the information policy of the Russian Federation Kremlin blocks access to archival materials, interferes in the educational process in the controlled territories in the East of Ukraine and the Crimea, in particular by changing academic programmes in such disciplines as history and law, implementing disciplinary and educational measures aimed at weakening and destroying historical memory and national consciousness, sense of patriotism, especially among the younger generation and overall population of Ukraine. The Russian Federation is trying to monitor information flows in the media and Internet resources, regulate the dissemination of the information under its state policy in its subordinate media outlets through information and communication technologies, which in their essence plays the role of propaganda. The main purpose of such actions is disorientation and manipulation of public opinion in Ukrainian society, circulation of destructive ideas and split up of society, psychological destabilization in Ukraine, and promotion of the belief that this country is, so to speak, a failed state. For example, during the local elections 2020 in Ukraine, Ukrainian media owned by pro-Russian tycoons disseminated Kremlin narratives about Ukraine as a "non-state entity," a "Nazi state," as well as about "external governance of Ukraine." According to the monitoring conducted by the NGO "Detector Media," the 12 most popular disinformation narratives are "external governance of Ukraine," a "threat of a coup d'état," "Zelensky deceived voters," "Zelensky is the second Poroshenko," "Maidan is a mistake," "civil war," the "loss of Crimea is Ukraine's fault," "Medvedchuk is Ukraine's hope," "Ukraine is a non-state entity," "Ukraine is a Nazi state," "Ukraine will be saved by friendship with Russia," "dissenters of the Orthodox Church of Ukraine" (Detector Media, 2020).

With this pessimistic approach to Ukraine, Russia hopes to discredit the Ukrainian government in the eyes of Europe and NATO, to destroy both domestic and international support to reforms that are intended to make Kyiv more independent from Moscow (Lucas, Pomerantsev, 2016). At the same time, such actions currently hinder the implementation of the national policy of historical memory in Ukraine. The latter is officially carried out at the national level and in the modern circumstances, especially after the Revolution of Dignity, is designed to become a key mechanism of national reconciliation, social consolidation, and civic mobilization (Babka, 2016, p. 159). As a means of influence, historical memory is a tool to overcome existing Soviet stereotypes in the public 
consciousness and patriotic mobilization, opposition to Russian propaganda in the Ukrainian society, and the substantial democratization of society and the rule of law. The Kremlin realizes this well and considers neighboring democracies and open societies as a threat because they might be "contagious" for the Russian Federation. Moreover, Russia's top political leadership believes that Russia has the right to a "grey zone" along its borders, a territory where the sovereignty of other nations is limited and Russian politicians and companies have a privileged economic and political status (Lucas, Pomerantsev, 2016).

In instrumentalizing the history of Ukraine, Russian spin doctors appeal predominantly to a "common historical past," "restoration of historical justice," and support separatist movements both in the East and in the West of Ukraine, initiating heated disputes over the language issue. At the same time, the Russian Federation persistently promotes and disseminates historical and political narratives through the media to justify its actions in eastern Ukraine and Crimea. These narratives include "Ukraine is an unsuccessful shadow of Russia," "Ukraine is an artificial project of the West," "the Crimea, Donbas and the south-east of Ukraine are parts of Russia," "USSR is a powerful empire," "Stalin is a hero," "All Ukrainian nationalists were fascists," "Ukraine forgot about the victory over Nazism" and others (Hrytsak, Galushko, Primachenko, 2019). However, the most extreme example of Russia's neo-imperial ambitions, which returns Russia to the geopolitics of the late nineteenth and early twenty-first centuries, is the appeal to the historical myth of the so-called "Novorossiya." A clear example of addressing these myths is their use by separatist forces in Crimea and eastern Ukraine.

Russia blatantly fills these narratives with misinformation, making sure that this lie is interesting and emotional, and adapts it to a strategic presentation according to the prejudices and perceptions of its audiences (Lucas, Pomerantsev, 2016). These and other revisionist historical efforts are accompanied by shuffled and fabricated facts, which the Russian propaganda machine actively disseminates. At the same time, the actions of historical policy actors are being exacerbated. In particular Russian scholars attempt to substantiate such myths and narratives with facts (Hrytsak, Galushko, Primachenko, 2019), and any criticism from the outside is refuted and rejected like all other negative comments about Russia, which are considered by the Kremlin either as fictitious or unfair and are the result of double standards and prejudices.

Nowadays, it has become commonplace to expand the tools of confrontation between countries through information. The Russian Federa- 
tion employs information not only as propaganda but as a modern weapon. It has become part of its aggressive foreign policy, which it pursues not only in the countries of the former Soviet bloc but also in other regions, primarily in the Middle East. In particular, Russia justifies its intervention in the events in Syria in 2015 because it fought against the extremist terrorist group "Islamic State." Thus, the Russian government desires to present Russia as a state that fights "for a just cause," to which civilized states cannot be indifferent (Skuczynski, 2016).

In the case of Ukraine, information confrontation is an important part of the hybrid war that Russia has waged against Ukraine with the use of force. The Russian Federation's information war against Ukraine is recognizable and obvious (Stadnyk, 2016, p. 114). Its initial stage dates back to 2007-2008 when Russia used its messages to prepare target audiences in Ukrainian society for the future support of its armed aggression. The war became large-scale after the events in November 2013 - February 2014, recorded in historiography as the Revolution of Dignity. Russia employs the latest information and communication technologies in this war. Technologies commonly used on Russian TV and radio channels to covertly influence consumers include the imposition of "portioned" information and misinformation, a combination of facts with personal opinions and assumptions, information reframing, providing "no comment" information to a pre-trained recipient of information, exaggeration and omission of truthful information.

One of the latest information and communication technologies extensively used by the Russian Federation today are historical documentaries, which impose Russian approaches to interpreting the history of Ukraine and the current events, thus distorting the past and present. Such films as "Ukraine Project," "Crimea. The Way Home," "Stepan Bandera. The Unveiled life," "Maidan. The technology of revolution," "Ukraine. Mazepa Operation" and many others are now intensively distributed in the media landscape. Russian myths and narratives are traced in them in any respect.

The Russian Federation leadership actively employs the technology of comprehensive repetitive propaganda, constantly covering it up. Thus, after the annexation of Crimea, the President of Russia, by a non-public decree, has awarded more than 300 employees of the Russian media, who in practice used propaganda methods "for high professionalism and objectivity in covering events in the Republic of Crimea." The list of award recipients includes journalists from the All-Russian State Television and Radio Broadcasting Company, Channel One, NTV, Russia Today, and 
Lifenews. Russia Today was founded by the Russian government in 2005 and is owned by the Russian International News Agency ("RIA Novosti"). Russia Today is broadcasted in more than 100 countries, and its website is available in six languages (Russian, English, Spanish, Arabic, German, and French). Russia Today is also active in social networks (Facebook "Russia Today" - 5.6 million likes, "Russia Today in Russian" - 1.6 million, Russia Today America - 1 million, Vkontakte group "Russia Today in Russian" -1.2 million subscribers, YouTube -3.7 million subscribers). Most researchers characterize Russia Today as the Kremlin's propaganda media. A comparative study of media coverage of the protests in Ukraine by BBC World, Al Jazeera English, CNN International, and Russia Today shows that the information provided by Russia Today is increasingly different from other media because the nationalist movements in Ukraine in 2013-2014 were represented as anti-Semitic and fascist movements. Moreover, Russia Today, more often than other agencies, emphasized violence in Ukraine (Galus, 2019, p. 34-35).

In addition to these media, the Kremlin uses Internet resources, social media accounts of allegedly independent journalists, political scientists, and experts, as well as, until recently operating traditional pro-Russian media in Ukraine - ZIK, TV Channel 112, NewsOne - the so-called "Medvedchuk channel group" (Viktor Medvedchuk, MP, the member of the pro-Russian faction "Opposition Platform - for Life," has personal contacts with Russian President Vladimir Putin). Their activities had a significant impact on the domestic situation in Ukraine. In particular, according to the Kyiv International Institute of Sociology, the virtual "Sharii Party," led by the pro-Russian video blogger A. Sharii, who spreads Russian propaganda and Ukrainophobia, is becoming increasingly popular among Ukrainian citizens (Danylenko, 2020, p. 31). The information war, which is part of the general war waged by the Kremlin against Ukraine acts as a strong mechanism for influencing and manipulating the public consciousness of the population of Ukraine.

Given this situation, the Russian Federation can be said to have been recently retargeting the use of so-called "attacks from the outside perimeter" when the emphasis was on traditional media (Sputnik news agency, Russia Today foreign broadcaster, Channel One, Russia 24, etc.) and their far-reaching propaganda among the citizens of Ukraine to the Ukrainian domestic environment using the tactics of creating agents of influence in media inside the country, which corresponds to the general strategy of forming chaotic socio-political conditions in Ukraine with its subsequent 
destruction as an independent political entity (Danylenko, 2020, p. 30). Such "agents of influence" were not only the media but also a department of the CIS Institute in Kyiv, some Russian "territorial communities," some politicians, and representatives of "compatriots abroad" (Kasyanov, 2014, p. 148). Therefore, under such circumstances, the political instrumentalization of Ukraine's history proved to be a very effective undermining force in Ukrainian society, especially with the establishment of the information society era in which media and information technologies have significantly expanded the possibility of manipulating the public consciousness.

Furthermore, Russian information and communication technologies are thoroughly coordinated, targeted, well-funded, and most professionally executed. American and European scholars study the Kremlin's ties with think tanks, universities, and research institutions in Russia, Europe, and the United States, through which Russia imposes its influence in the information environment of Western countries. In particular, researchers emphasize that Russia operates in the international arena following its "neoconservative doctrine," the features of which are the denial of Russia's responsibility for aggression, historical revisionism, constant criticism of the West encouraging and maintaining separatism in European countries, etc. In the run-up to the 2016 Duma elections, the Institute for Social-Economic and Political Studies of Russia set up a state-funded think tank, Rethinking Russia (RR), to disseminate the United Russia party's political propaganda to the international audience. The reports produced by this think tank have extensive coverage and are targeted at Western experts and journalists. For instance, a report entitled «Russia's Political System from 2011 to 2016 State Duma Election Campaigns» was sent to 6,000 Western journalists and experts. Moreover, some researchers believe that this analytical center also had an office in Brussels (Smagliy, 2018, p. 14).

In recent years, Russia's disinformation activities have met almost no effective resistance in Ukraine. This situation results from the belated formation of the unified state information strategy due to political, financial, and personnel problems, which led to a confrontation with Russian information aggression only at the tactical decision level, which often are behindhand. The shortage of coordination efforts of civil society representatives and mass media is also observed and confirms the long-term deficiency of coordination in information counteraction at the national level. The dominance of TV channels controlled by oligarchic entities, 
the weakness of public broadcasting in Ukraine, comprador behavior of some journalist circles, and the extremely low level of critical thinking and media literacy of Ukrainians are among the negative factors of the information field. There is also an insufficiency of legal and institutional frameworks to counter misinformation.

Nowadays, these gaps are sophisticated not only by the need to address many economic and financial issues but also by the latest problem, such as COVID-19, which requires an urgent response from the state. At the same time, there is a manipulation of information on the coronavirus (Meduza, 2020), which takes place in the Russian and other media space. One of the main narratives here is the «creation» of the virus in an American laboratory located in Ukraine, which attempts to portray it as a country under the external influence of foreign governments and international organizations (Damian, Subernitchi, 2020). This misleading information often distracts international and Ukrainian society from the political realities in which the Kremlin is involved. This distraction favors the Russian Federation because, in search of its potential followers, the basic Russian narratives are supported by tactics aimed at the audience that is not very interested in complex political issues. Although the main goals of Russian disinformation remain unchanged, the spread of false news about COVID-19 has given Russia new opportunities to present itself as a potential rescuer, providing humanitarian aid and free vaccines to countries in need (especially in the post-Soviet states), and at the same time criticize the West and even the existing international order (Olkhovskii, 2020, p. 26).

The trap of Russian propaganda is the current emphasis in Ukrainian society on the right or wrong view of history in the light of contemporary events, which leads to ignoring the fact that in the occupied territories live people who want to be in Ukraine but do not share certain attitudes to events in the history of Ukraine. It is also intolerable to neglect the fact that there are people in the unoccupied territory who are under the influence of Russian propaganda and disloyal to the Ukrainian authority (Babka, 2016, p. 172). The use of the Ukrainian authorities' drawbacks by the Russian Federation is obvious. The latter, using the political instrumentalization of history that is at the heart of its historical policy, hopes to further radical stirring up of its potential supporters in the Crimea, eastern and southern regions of Ukraine to maintain its military presence in the occupied parts of Ukraine and further military campaigns in those regions.

Currently, Ukraine needs to elaborate a new effective policy for the protection of national interests. A great example is the experience of the 
State of Israel, which has successfully combined the work of the military, special services, and the media around the world. It proves that mass media should be seen as the major developer and responsible party for executing projects in information and psychological operations (Danylenko, 2015, pp. 312-313). One of the directions of this policy should be to ensure the spread of Ukraine's overseas broadcasting in as many countries as possible, which can potentially become Ukraine's partners or allies. Such international broadcasting will also ensure forehanded counteraction to Russia's information aggression. In addition, misinformation about Ukraine should be exposed by established organizations (agencies, centers, etc.) investigating Russian (or any other) disinformation campaigns and debunk their invalidity for targeted audiences that can accept fact-based evidence. A broader analysis of the media environment, the scope, and the impact of Russian propaganda would ensure the detection of disinformation campaigns and understanding what sources influence the public consciousness. In order to avoid manipulation of public opinion and collective public consciousness, which takes place in the course of political instrumentalization of Ukrainian history, a working group of specialists in the field of history, political science, psychology, and mass media should operate with the support of the state and based on the latest scientific tendencies and approaches should debunk fake political narratives and other kinds misinformation about Ukraine's history and current developments in our state as well as with the help of modern media would disseminate truthful information among the population of the country and the international community. In this context, the activity of the Security Service of Ukraine should be intensified.

\section{Conclusions and possibilities for future research}

Thus, with the refocusing to the internal Ukrainian environment, the Russian Federation actively uses the instrumentalization of history and the tactics of forming "media agents of influence" inside the country. This domain of the information confrontation also confirms that Russian propaganda is characterized by: a) flexibility, b) involvement of various topics - from politics to sports, c) its long-term duration, d) and by narratives which are the key tool of misinformation influence. Ukraine has failed to introduce own positive rhetoric on this issue, which would be the asymmetric proactive response. In addition, oligarchic control over 
media resources in Ukraine (primarily television) facilitates the penetration of destructive Russian narratives, including historical ones, into the information space of Ukraine.

Therefore, the recent closure of the pro-Russian TV channels by the National Security and Defense Council of Ukraine has shown that this issue is now classified at the highest political level as protecting national sovereignty and territorial integrity and is clearly distinguished from the basic democratic value called freedom of speech. Suppose the authorities manage to defend this decision through legal action both in the Ukrainian and European judiciary. In that case, it will be a new precedent, when internal sanctions of the Ukrainian government blocked the work of media agents who settled down not outside the national information field (as it was in the case of blocking Russian TV channels in 2014 or social networks in 2017) but were embedded in the structure of the Ukrainian information field. Pro-Russian broadcasters have proved to be a very effective destabilizing force in Ukrainian society, especially with the establishment of the information age, in which media information technologies have significantly expanded the possibility of manipulating public consciousness. Our previous research specified that the concentration of pro-Russian media resources in recent years in Ukraine was defined as a destructive information influence strategy. Recently, the Kremlin has been using information not only as propaganda but as a modern weapon. It should be noted that propaganda becomes most effective when the system of its production and promotion meets the requirements of institutionalization, which includes the presence of formal and real centers, government procurement and control over the implementation of propaganda tasks as well as the formation of appropriate personnel, political and other resources. The Russian Federation's information war against Ukraine is a fait accompli and is part of a hybrid war waged by Russia using force.

In the information war against Ukraine, the Kremlin uses the latest information and communication technologies, including the imposing of "portioned" information and misinformation, a combination of facts with personal opinions and assumptions, information reframing, providing "no comment" information to a pre-trained recipient of information, exaggeration and omission of truthful information.

With the employment of media communication, Russia persistently promotes and disseminates historical and political narratives, filling them with misinformation and lies while endeavoring that this information is perceived with interest and strong emotions, strategically adapting it to 
the prejudices and perceptions of specific target audiences. At the same time, Russian scholars are striving to substantiate such myths and narratives to justify Russia's aggressive actions in eastern Ukraine and Crimea.

So far as Russian information and communication technologies are carefully coordinated and targeted, well-funded and predominantly professionally executed and the belated establishment of a unified information strategy in Ukraine due to political, financial, and personnel problems, insufficiency of efforts of the civil society, and mass media counteraction to Russian information aggression is conducted preferably at the level of the tactical decision which often are behindhand as well. Therefore, there is an urgent need to elaborate an effective policy in the field of counteracting the political instrumentalization of the Ukrainian history and information aggression in general, developing in this context a powerful and functional mechanism of action that is part of the protection of Ukraine's national interests.

\section{Bibliography}

Aaltola M. (2021), "Democratic Vulnerability and Autocratic Meddling: The Thucydidean Brink”, https://www.ncbi.nlm.nih.gov/pmc/articles/PMC7981554/.

Babka V. (2016), "Historical memory as a factor of political influence in independent Ukraine", Thesis for Cand. Sc. (Political culture and ideology), 23.00.03 - Nizhyn Gogol State University, 244 p.

Baluk W. (2020), Polska na celowniku Putina. Narracja rosyjskiej propagan$d y w$ sprawie wybuchu II wojny światowej, https://phavi.umcs.pl/at/ attachments/2020/0907/112151-biuletyn-politologiavissn.pdf, 24.02.2021.

Bondarenko I. (2019), Information component of the hybrid war of the Russian Federation against Ukraine, "Actual problems of information security management of the state", pp. 13-15.

Damian A., Subernitchi V. (2020), Conspiracy theories and pro-Russian propaganda in EaP countries. Driving factors and potential beneficiaries, "CRPE Policy Brief”, https://www.crpe.ro/en/conspiracy-theories-and-pro-russianpropaganda-in-eap-countries-driving-factors-and-potential-beneficiaries/, 24.02.2021.

Danylenko S. (2020), Koncentracja prorosyjskich zasobów medialnych jako strategii niszczacego wpływu informacji na Ukraine, https://phavi.umcs.pl/at/ attachments/2020/0907/112151-biuletyn-politologiavissn.pdf (In Ukrainian), 24.02.2021.

Danylenko S. (2015), Mental, cultural and political consequences of Russia's information aggression against Ukraine and ways to overcome it, "Problems of international relations", issue no. 10-11, pp. 303-315 (In Russian). 
Detector Media (2020), Ukrainian media spread Kremlin narratives about Ukraine as a "non-state", "Nazi state" and its "external management" - monitoring, https://detector.media/infospace/article/181371/2020-10-08-ukrainski-media-poshyryuyut-kremlivski-naratyvy-pro-ukrainu-yak-nedoderzhavu-natsystsku-derzhavu-ta-zovnishnie-upravlinnya-neyu-monitoryng (In Ukrainian).

Galus A. (2019), Digital media in a contemporary conflict - example of Ukraine, "Środkowoeuropejskie Studia Polityczne", issue no. 4, pp. 27-46.

Hrytsak Y., Galushko K., Primachenko Y. et al. (2019), Revision of History. Russian historical propaganda and Ukraine, http://resource.history.org.ua/ item/0014736 (In Ukrainian), 24.02.2021.

Kasyanov G. (2014), Historical policy of the 1990s-early XXI century: Ukraine and the post-Soviet space, "Modern Ukraine”, issue no. 21, pp. 135-159.

Kofman M. (2017), Lessons from Russia's Operations in Crimea and Eastern Ukraine, RAND Corporation, 128 p., https://www.rand.org/content/dam/rand/pubs/research_reports/RR1400/RR1498/RAND_RR1498.pdf.

Lucas E., Pomerantsev P. (2016), The purpose of Russian propaganda - to sow despair and paranoia. How to counteract, https://texty.org.ua/articles/70089/ Meta_rosijskoji_propagandy_posijaty_zneviru_i-70089/ (In Ukrainian), 24.02.2021.

Meduza (2020), "Letter of the Belgian doctors" - a fundamental manifesto of covid deniers, https://meduza.io/feature/2020/10/19/pismo-belgiyskih-vracheyfundamentalnyy-manifest-kovid-otritsateley-my-izuchili-istoriyu-egopoyavleniya-i-razobrali-glavnye-argumenty (In Russian), 24.02.2021.

Miller A. (2020), "Russia and Europe in memory wars", NUPI Working Paper 887, Norwegian Institute of International Affairs, 20 p.

Olkhovskii J. (2020), Infodemia - dezinformacja w czasach zarazy, https://phavi. umcs.pl/at/attachments/2020/0907/112151-biuletyn-politologiavissn.pdf.

Olkhovskii J. (2019), Polish-Ukrainian relations in the policy of (dis)information of the Russian Federation, "Ukrainian-Polish relations in terms of hybrid security threats", pp. 216-231 (In Ukrainian), 24.02.2021.

Shevchuk P. (2014), Information and psychological war of Russia against Ukraine: how to counter it, http://nbuv.gov.ua/UJRN/DeVr_2014_13_11 (In Ukrainian), 24.02.2021.

Skuczynski M. (2016), Interesy narodowe Federacji Rosyjskiej w Syrii na tle rosyjskiej interwencji w 2015 roku, http://studiastrategiczne.amu.edu.pl/wp-content/ uploads/2016/11/10.pdf, 24.02.2021.

Smagliy K. (2018), Hybrid analytica: pro-Kremlin expert propaganda in Moscow, Europe and the U.S. A case study on think tanks and universities, https:// static1.squarespace.com/static/59f8f41ef14aa13b95239af0/t/5c6d8b38b208f c7087fd2b2a/1550682943143/Smagliy_Hybrid-Analytica_10-2018_upd.pdf, 24.02.2021. 
SNIP (2017), Ukrainian "Breeze” from the Crimea: 23 years on the air, http://snip. net.ua/20171122/ukrayinskyj-bryz-iz-krymu-23-roky-v-efiri/ (In Ukrainian), 24.02.2021.

Stadnyk A. (2016), Information war as a communicative technology of influence on mass consciousness and public opinion, "Grani. Sociology", issue no. 1, pp. 111-115 (In Ukrainian).

Sweet J. (2016), Political Invasions into Collective Memories: Russia, "International Journal of Communication", https://ijoc.org/index.php/ijoc/article/viewFile/4406/1781.

Yablonsky V., Valevsky O., Zdioruk S. et al. (2019), The policy of historical memory in the context of national security of Ukraine: an analytical report, https:// niss.gov.ua/sites/default/files/2019-09/dopovid_polityka_druk_03.pdf Ukrainian), 24.02.2021.

\section{Wykorzystanie rosyjskich technologii informacyjno-komunikacyjnych w instrumentalizacji politycznej historii Ukrainy}

\section{Streszczenie}

W artykule omówiono polityczną instrumentalizację dziejów Ukrainy prowadzoną przez Federację Rosyjską w ramach wojny informacyjnej z Ukrainą. Ta instrumentalizacja jest realizowana poprzez komunikację medialną, wykorzystującą mity i narracje historyczne i polityczne, aby usprawiedliwić agresywne działania Rosji. W artykule zidentyfikowano najnowsze technologie informacyjno-komunikacyjne wykorzystywane przez Kreml w wojnie informacyjnej z Ukrainą. Takie destrukcyjne wysiłki często negatywnie wpływają na stosunki ukraińsko-polskie, które są szczególnie wrażliwe na kwestie historyczne i polityczne.

Słowa kluczowe: dezinformacja, wojna informacyjna Rosji z Ukrainą, polityczna instrumentalizacja historii, media 
